\title{
CFD Model of a Planar Solid Oxide Electrolysis Cell: Base Case and Variations
}

\section{ASME-JSME Thermal Engineering Summer Heat Transfer Conference}

\author{
Grant Hawkes \\ Russell Jones
}

July 2007

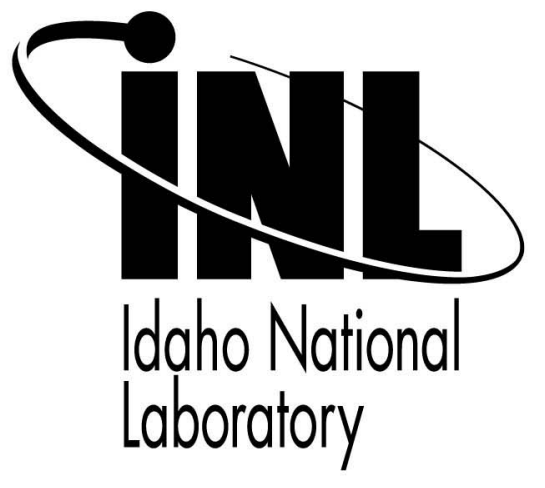

This is a preprint of a paper intended for publication in a journal or proceedings. Since changes may be made before publication, this preprint should not be cited or reproduced without permission of the author. This document was prepared as an account of work sponsored by an agency of the United States Government. Neither the United States Government nor any agency thereof, or any of their employees, makes any warranty, expressed or implied, or assumes any legal liability or responsibility for any third party's use, or the results of such use, of any information, apparatus, product or process disclosed in this report, or represents that its use by such third party would not infringe privately owned rights. The views expressed in this paper are not necessarily those of the United States Government or the sponsoring agency. 


\author{
Proceedings of HT2007 \\ 2007 ASME-JSME Thermal Engineering Summer Heat Transfer Conference \\ July 8-12, 2007, Vancouver, British Columbia, CANADA
}

HT2007-32310

\title{
CFD MODEL OF A PLANAR SOLID OXIDE ELECTROLYSIS CELL: BASE CASE AND VARIATIONS
}

\author{
Grant Hawkes, Idaho National Laboratory (INL)
}

\section{ABSTRACT}

A three-dimensional computational fluid dynamics (CFD) model has been created to model high-temperature steam electrolysis in a planar solid oxide electrolysis cell (SOEC). The model represents a single cell, as it would exist in an electrolysis stack. Details of the model geometry are specific to a stack that was fabricated by Ceramatec, Inc ${ }^{1}$. and tested at the Idaho National Laboratory. Mass, momentum, energy, and species conservation and transport are provided via the core features of the commercial CFD code FLUENT ${ }^{2}$. A solid-oxide fuel cell (SOFC) module adds the electrochemical reactions and loss mechanisms and computation of the electric field throughout the cell. The FLUENT SOFC user-defined subroutine was modified for this work to allow for operation in the SOEC mode. Model results provide detailed profiles of temperature, Nernst potential, operating potential, activation over-potential, anode-side gas composition, cathode-side gas composition, current density and hydrogen production over a range of stack operating conditions. Mean model results are shown to compare favorably with experimental results obtained from an actual ten-cell stack tested at INL.

Mean per-cell area-specific-resistance (ASR) values decrease with increasing current density, consistent with experimental data. Predicted mean outlet hydrogen and steam concentrations vary linearly with current density, as expected. Effects of variations in operating temperature, gas flow rate, cathode and anode exchange current density, and contact resistance from the base case are presented.

Discussion of thermal neutral voltage, enthalpy of reaction, hydrogen production, cell thermal efficiency, cell electrical

\footnotetext{
1,2 References herein to any specific commercial product, process, or service by trade name, trademark, manufacturer, or otherwise, does not necessarily constitute or imply its endorsement, recommendation, or favoring by the U.S. Government, any agency thereof, or any company affiliated with the Idaho National Laboratory
}

\author{
Russell Jones, Idaho State University
}

efficiency, and Gibbs free energy are discussed and reported herein.

\section{INTRODUCTION}

A research program is under way at the Idaho National Laboratory (INL) to simultaneously address the research and scale-up issues associated with the implementation of planar solid-oxide electrolysis cell technology for hydrogen production from steam. The research program includes an experimental program aimed at performance characterization of electrolysis cells and stacks. Results of some multi-cell tests have been documented in several recent papers [1], [2]. This paper reports the sensitivity of various parameters changed when modeling a planar solid oxide electrolysis cell (SOEC) with the FLUENT code and SOFC module [3]. This code was used for detailed SOEC modeling. Fluent Inc. was funded by the US Department of Energy National Energy Technology Laboratory (DOE-NETL) to develop a solid-oxide fuel cell (SOFC) module for coupling to the core mass, momentum, energy, and species conservation and transport features of the FLUENT CFD code. The SOFC module adds the electrochemical reactions and loss mechanisms and computation of the electric field throughout the cell. The FLUENT SOFC user-defined subroutine was modified for this work to allow for operation in the SOEC mode. Model results provide detailed profiles of temperature, Nernst potential, operating potential, anode-side gas composition, cathode-side gas composition, current density and hydrogen production over a range of stack operating conditions. Reference [4] has details of the FLUENT code and numerical model. Results of the numerical model are shown in this paper. When predicting experimental results, empiricism arises. When trying to predict experimental results with this SOEC model, the only way to match the experimental data is to change the parameters shown in this paper. This paper shows the effect the different parameters have on changing the $V-i$ curve when trying to match experimental results. 


\section{NOMENCLATURE}

$\begin{array}{ll}A S R & \text { area specific resistance, } \Omega-\mathrm{cm}^{2} \\ E & \text { voltage potential, } \mathrm{V} \\ F & \text { Faraday constant, } 96487 \mathrm{~J} / \mathrm{V} \text {-mol } \\ \Delta G & \text { Gibbs free energy, } \mathrm{J} / \mathrm{mol} \\ \Delta H & \text { molar enthalpy of reaction, } \mathrm{J} / \mathrm{mol} \\ I & \text { current, A } \\ j & \text { electrons transferred per } \mathrm{H} 2 \text { molecule } \\ K & \text { permeability, }{ }^{2} \\ k & \text { thermal conductivity, } \mathrm{W} / \mathrm{m}^{2}-\mathrm{K} \\ \dot{N} & \text { molar flow rate, } \mathrm{mol} / \mathrm{s} \\ P & \text { pressure in stack, } \mathrm{Pa} \\ Q & \text { external heat transfer, } \mathrm{W} \\ R & \text { universal gas constant, } \mathrm{J} / \mathrm{mol}-\mathrm{K} \\ T & \text { temperature, } \mathrm{K} \\ V & \text { voltage, Volts } \\ W & \text { work, product of } \mathrm{I} * \mathrm{~V}, \mathrm{~W} \\ y & \text { molar fraction }\end{array}$

\section{Greek Letters}

$\begin{array}{ll}\varphi & \text { porosity } \\ \rho & \text { specific resistance } \Omega-\mathrm{m} \\ \eta & \text { efficiency }\end{array}$

Subscripts

$\begin{array}{ll}\text { act } & \text { activation overpotential } \\ \mathrm{H} 2 & \text { Hydrogen gas } \\ \mathrm{H} 2 \mathrm{O} & \text { steam } \\ m f & \text { mass fraction } \\ \mathrm{O} & \text { open-cell } \\ \mathrm{O} 2 & \text { Oxygen } \\ \mathrm{R} & \text { reaction } \\ \text { std } & \text { standard pressure } \\ t n & \text { thermal neutral } \\ t & \text { thermal }\end{array}$

\section{NUMERICAL MODEL}

The numerical model developed for this paper was based on the geometry of a single SOEC cell taken from a stack designed and fabricated by Ceramatec, Inc. and tested at the INL. A photograph of this stack is shown in Figure 1. The stack has a per-cell active area of $64 \mathrm{~cm}^{2}$. It is designed to operate in cross flow, with the steam/hydrogen gas mixture entering the inlet manifold on the right in the photograph, and exiting through the outlet manifold, visible on the left in the photograph. Air flow enters at the rear though an air inlet manifold (not visible in Fig. 1) and exits at the front directly into the furnace. The power lead attachment tabs, integral with the upper and lower interconnect plates are also visible in the photograph.
The numerical model geometry represents a single cell, as it would exist in the stack. The numerical domain extends from the bottom of the hydrogen side current collector to the top of the oxygen side current collector as shown in Figure 2.

The FLUENT SOFC module treats the electrolyte as a 2-D planar element. Therefore the electrolyte in the model has geometrical thickness of zero. On either side of the electrolyte are the electrodes that are created with 3-D elements. Therefore, the electrolyte/electrode assembly in the model is only as thick as the two electrodes.

The numerical grid used in this study included 6 elements each in the flow inlet and outlet regions, and $30 \times 30$ in the active cell area in the $\mathrm{X}$ and $\mathrm{Y}$ directions and 24 elements through the thickness. Inlet and outlet flow regions were included in the model so that no numerical gradients would exist at the active cell area. Each flow channel (current collector) has 10 elements through its thickness, whereas each electrode has two elements through its thickness. Two views of the numerical grid used in the FLUENT model are shown in Figure 3. Figure 3(a) is a corner view showing 28 elements stacked in the z-direction, representing 5 distinct layers. Figure 3 (b) is a top view showing the $42 \times 42$ element grid pattern used in the model. The center layers visible in Figure 3(a) represent the electrode regions. There are 2 elements for each electrode layer. Note that since the FLUENT SOFC module treats the electrolyte as a 2-D planar element, the electrolyte is not visible in Figure 3(a). Reference [4] shows the sensitivity to grid and will not be discussed in this report.

Shown in Table 1 are the geometric and input parameters for the base case of this model. Parameters include thickness, thermal conductivity, specific resistivity, porosity, tortuosity and permeability.

Table 2 shows the base case with the parameters that are varied for eight cases. Additional parameters specified in the numerical model include the electrode exchange current densities, mass flow rates, electrolyte ionic conductivity, gap electrical contact resistance, and concentration exponent used in activation overpotential.

All external surfaces are considered to be adiabatic. The gas flow inlets are specified in the FLUENT model as massflow inlets, with the gas inlet temperatures are set at $1073 \mathrm{~K}$ and the inlet gas composition determined by specification of the mass fraction of each component. The gas flow rates used in the model are shown in Table 2.

Details of the core mass, momentum, energy, and species conservation and transport features of FLUENT are documented in detail in the FLUENT user manual from Fluent Inc. Details of the electrochemical reactions, loss mechanisms, electric field computation, and electrode porous media constitutive relations are documented by the SOFC module in the FLUENT documentation. This reference also documents the treatment of species and energy sources and sinks arising from the electrochemistry at the electrode-electrolyte interfaces. 


\section{DISCUSSION}

In the electrolysis mode, the net heat flux is negative at low current densities, increasing to zero at the "thermalneutral" voltage, and positive at higher current densities. Assuming the process occurs at a specified temperature, the thermal-neutral voltage can be predicted from direct application of the First Law to the overall system:

$$
Q-W=\dot{N}_{H 2} \Delta H_{R}
$$

Letting $Q=0$ (no external heat transfer), $W=V I$, and noting that the electrical current is directly related to the molar production rate of hydrogen by

$$
\dot{N}_{H 2}=I / 2 F
$$

where $F$ is the Faraday number $(F=96,487 \mathrm{~J} / \mathrm{V} \mathrm{mol})$, yields:

$$
V_{t n}=-\Delta H_{R} / 2 F
$$

Since the molar enthalpy of reaction, $\Delta H_{R}$, is strictly a function of temperature (albeit a very weak function), the thermal-neutral voltage is also strictly a function of temperature, independent of cell ASR and gas compositions. The particular values of net cell heat flux at other operating voltages do however depend on cell ASR and gas compositions. The thermal-neutral voltage increases only slightly in magnitude over the typical operating temperature range for steam electrolysis cells, from $1.287 \mathrm{~V}$ at $800^{\circ} \mathrm{C}$ to $1.292 \mathrm{~V}$ at $1000^{\circ} \mathrm{C}$. Stack operation at or below the thermalneutral voltage simplifies thermal management of the stack since excess air flow is not required. In fact, in the electrolysis mode, since oxygen is being produced, there is also no theoretical need for air flow to support the reaction at all. In a large-scale electrolysis plant, the pure oxygen produced by the process could be saved as a valuable commodity. Careful consideration must be given, however, to the choice of materials for containing pure oxygen at elevated temperatures. In addition, it may be desirable to sweep with air or some other gas in order to minimize the effects of any hydrogen leakage.

A thermal efficiency, $\eta_{t}$, can be defined for electrolysis cells, analogous to the fuel cell efficiency definition presented in textbooks on fuel cells. The thermal efficiency quantifies the heating value of the hydrogen produced by electrolysis per unit of electrical energy consumed in the stack. Based on this definition,

$$
\eta_{t}=\frac{\Delta H_{R} \dot{N}_{H 2}}{V I}
$$

Eliminating the current $\mathrm{I}$, the thermal efficiency can be expressed in terms of cell operating potential as:

$$
\eta_{t}=\frac{\Delta H_{R} / 2 F}{V}=\frac{V_{t n}}{V} .
$$

The thermal efficiency for the fuel-cell mode of operation is the inverse of Eqn. (5).

It should be noted that the value of the thermal efficiency defined in this manner for electrolysis can exceed 1.0. As an example, for the reversible stoichiometric case, the cell potential approaches reference open-cell value, $E_{o}=\Delta G_{R} / 2 F$, yielding:

$$
\eta_{t, \max }=\frac{\Delta H_{R}}{\Delta G_{R}}
$$

which for steam electrolysis at $850^{\circ} \mathrm{C}$ is equal to 1.34 . For cases with variable gas concentrations, the open-cell potential is given by the Nernst Equation, which for the hydrogen/oxygen/steam system takes the form:

$$
E=E_{O}-\frac{R T}{j F} \ln \left[\left(\frac{y_{H 2 O}}{y_{H 2} y_{O 2}^{1 / 2}}\right)\left(\frac{P}{P_{s t d}}\right)^{-1 / 2}\right]
$$

FLUENT calculates the activation over-potential by the following set of equations. The parameter of 1000 and 4000 $\mathrm{A} / \mathrm{m}^{2}$ used in the variations for the different cases is $i$, 0 ref.

$$
i_{0 \text { eff }}=i_{0, \text { ref }}\left(Y_{j}\right)^{\gamma}
$$

Where $\left(Y_{j}\right)$ is the mole fraction and $\gamma$ is the concentration exponent usually set to 0.5 . With $i$ being the local current density, the activation potential for the cathode and anode can then be calculated as:

$$
V_{a c t}=\frac{2 R T}{j F}-\sinh ^{-1}\left(\frac{i}{i_{0 e f f}}\right)
$$

\section{RESULTS}

Results of the FLUENT simulations obtained for various cases are presented in Figures 4 through 16. Figure 4 shows the current density contours for an operating voltage of 1.287 V. Steam/hydrogen flow is from the top down. Highest current densities occur at the top of the model where the steam concentration is the highest. Figure 5 shows the operating voltage versus current density curve for the base case and the eight cases. Case 1 shows a lower operating voltage (compared to the base case), at high current density because the mass flow of steam is higher which increases the numerator in Eq (7). Cases 2 and 3 have lower voltage because of the higher exchange current densities that show in Eq ( 8 and 9). Case 4 has a lower voltage with the lower specific resistivity of the electrolyte. Case 5 has the highest voltage because of the large change in the contact resistance. Case 6 is dominated by the effect of the higher contact resistance when all of the variations 
are combined. Cases 7 and 8 show the effect of changing the exponent $\gamma$ in $\mathrm{Eq}(8)$ and $\mathrm{Eq}(9)$. With $\gamma=1.0$ the Vop is higher due to the higher activation overpotential.

Figure 6 shows the temperature contours at 5 amps or $1.08 \mathrm{~V}$. The temperature at the inlet channels is $1073 \mathrm{~K}$. The minimum temperature in the model is $1017.97 \mathrm{~K}$. In this region of operation, the endothermicity of the reaction is dominating the Ohmic heating. Figure 7 shows the mean electrolyte temperature versus operating voltage for the various cases. This FLUENT model shows exact agreement with theoretical with these temperatures at the outlet being the same as the inlet at the thermal neutral condition. Notice how each case passes through $1073 \mathrm{~K}$ at the operating voltage of $1.287 \mathrm{~V}$. Figure 8 shows the average outlet gas temperature versus operating voltage.

Figure 9 shows the Nernst potential on the electrolyte for an operating voltage of $1.287 \mathrm{~V}$. Eq (7) describes the Nernst potential equation. Since the temperature is essentially isothermal, all of the variations occur because the mole fraction of each component varies as the flows go through the cell. Figure 10 shows the variations for each case of the Nernst potential versus current density.

Figure 11 shows the per-cell area-specific resistance (ASR) versus current density for the various cases. The ASR is based on the open cell voltage $(\mathrm{OCV})$. The $A S R=\left(\mathrm{V}_{\text {op }}-\mathrm{V}_{\mathrm{OCV}}\right) / \mathrm{i}$.

Figures 12 through 14 show the mole fraction for $\mathrm{H} 2$, $\mathrm{H} 2 \mathrm{O}$, and $\mathrm{O} 2$ respectively. The $\mathrm{H} 2 / \mathrm{H} 2 \mathrm{O}$ flows from the top down, while the $\mathrm{O} 2$ flows from left to right. These three plots are for an operating voltage of $1.287 \mathrm{~V}$.

Figure 15 shows the outlet mole fraction of $\mathrm{H} 2, \mathrm{H} 2 \mathrm{O}$, and $\mathrm{O} 2$ as a sweep of current density for the base case. H2 production and $\mathrm{H} 2 \mathrm{O}$ consumption are linear with current as expected. Figure 16 shows the total activation overpotential (anode and cathode) for each case.

\section{CONCLUSIONS}

A three-dimensional computational fluid dynamics (CFD) model has been created to model high-temperature steam electrolysis in a planar solid oxide electrolysis cell (SOEC). Effects of the variation of input parameters are shown for this cell and model. The model represents a single cell as it would exist in an electrolysis stack without the separator plates. Details of the model geometry are specific to a stack that was fabricated by Ceramatec, Inc. and tested at the Idaho National Laboratory. Mass, momentum, energy, and species conservation and transport are provided via the core features of the commercial CFD code FLUENT. A solid-oxide fuel cell (SOFC) model adds the electrochemical reactions and loss mechanisms and computation of the electric field throughout the cell. The FLUENT SOFC user-defined subroutine was modified for this work to allow for operation in the SOEC mode. Model results provide detailed profiles of temperature, Nernst potential, operating potential, anode-side gas composition, cathode-side gas composition, current density and hydrogen production over a range of stack operating conditions. Mean per-cell ASR values decrease with increasing current density, consistent with experimental data. Predicted mean outlet hydrogen and steam concentrations vary linearly with current density, as expected. Effects of variations in operating temperature, gas flow rate, and contact resistance from the base case were presented. Contour plots of local electrolyte temperature, current density, and Nernst potential indicated the effects of heat transfer, reaction cooling/heating, and change in local gas composition.

\section{ACKNOWLEDGMENTS}

The U.S. Department of Energy, Office of Nuclear Energy, Nuclear Hydrogen Initiative Program supported this work. The DOE National Energy Technology Laboratory (NETL) provided the SOFC module to the INL for this research. The Idaho National Laboratory is operated by the Battelle Energy Alliance through DOE Contract DE-AC07-05ID14517.

\section{COPYRIGHT STATEMENT}

This manuscript has been authored by Battelle Energy Alliance, LLC under Contract No. DE-AC07-05ID14517 with the U.S. Department of Energy. The United States Government retains and the publisher, by accepting the article for publication, acknowledges that the United States Government retains a nonexclusive, paid-up, irrevocable, world-wide license to publish or reproduce the published form of this manuscript, or allow others to do so, for United States Government purposes.

\section{REFERENCES}

1) J. E. O'Brien, C. M. Stoots, J. S. Herring, and J. J. Hartvigsen, "High Temperature Electrolysis for Hydrogen Production from Nuclear Energy," Nuclear Technology, May 2007.

2) J. E. O'Brien, C. M. Stoots, J. S. Herring, and J. J. Hartvigsen, "Hydrogen Production Performance of a 10Cell Planar Solid-Oxide Electrolysis Stack," Journal of Fuel Cell Science and Technology, Vol. 3, pp. 213-219, May, 2006.

3) Prinkey, M., Shahnam, M., and Rogers, W. A., "SOFC FLUENT Model Theory Guide and User Manual," Release Version 1.0, FLUENT, Inc., 2004.

4) G. L. Hawkes et. al., "CFD Model of a Planar Solid Oxide Electrolysis Cell for Hydrogen Production from Nuclear Energy", Paper LOG \# 326, The 11th International Topical Meeting on Nuclear Reactor Thermal-Hydraulics (NURETH-11), Avignon, France, October 2-6, 2005. 
Table 1. Material properties and dimensions of model.

\begin{tabular}{|c|c|}
\hline $\begin{array}{l}\text { Material properties (at } 1073 \mathrm{~K} \text { ) } \\
\rho \mathrm{O} 2 \text { electrode }(\Omega-\mathrm{m}) \\
\rho \mathrm{H} 2 \text { electrode }(\Omega-\mathrm{m}) \\
\rho \text { electrolyte }(\Omega-\mathrm{m}) \\
\rho \text { flow channels }(\Omega-\mathrm{m}) \\
k \mathrm{O} 2 \text { electrode }(\mathrm{W} / \mathrm{m}-\mathrm{K}) \\
k \mathrm{H} 2 \text { electrode }(\mathrm{W} / \mathrm{m}-\mathrm{K}) \\
k \text { electrolyte }(\mathrm{W} / \mathrm{m}-\mathrm{K}) \\
k \text { O2-flow channel }(\mathrm{W} / \mathrm{m}-\mathrm{K}) \\
k \mathrm{H} 2 \text {-flow channel }(\mathrm{W} / \mathrm{m}-\mathrm{K})\end{array}$ & $\begin{array}{l}1.425 \times 10^{-4} \\
8.856 \times 10^{-6} \\
0.5 \\
1.176 \times 10^{-6} \\
9.6 \\
13.1 \\
2.16 \\
27.0 \\
72.0\end{array}$ \\
\hline $\begin{array}{l}\text { Activation polarization } \\
i_{0, \text { ref }} \text { Cathode }\left(\mathrm{A} / \mathrm{m}^{2}\right) \\
i_{0, \text { ref }} \text { Anode }\left(\mathrm{A} / \mathrm{m}^{2}\right) \\
\end{array}$ & $\begin{array}{l}1000 \\
1000 \\
\end{array}$ \\
\hline $\begin{array}{l}\text { Diffusion pola rization } \\
\phi \text { electrodes }(\%) \\
\phi \text { flow channels }(\%) \\
L_{t} \text { electrodes } \\
K \text { electrodes }\left(\mathrm{m}^{2}\right) \text { (isotropic) } \\
K \text { flow channels }\left(\mathrm{m}^{2}\right) \\
\text { In the flow direction } \\
\text { Perpendicular to the flow direction }\end{array}$ & $\begin{array}{l}37 \\
87 \\
3.0 \\
1 \times 10^{-13} \\
2 \times 10^{-4} \\
2 \times 10^{-5}\end{array}$ \\
\hline $\begin{array}{l}\text { Dimensions (width } \mathbf{x} \text { length } \mathbf{x} \text { thickness) } \\
\mathrm{H} 2 \text { current collector / flow channel }(\mathrm{mm}) \\
\mathrm{H} 2 / \mathrm{O} 2 \text { inlet and outlet flow channels }(\mathrm{mm}) \\
\mathrm{H} 2 \text { electrode }(\mathrm{mm}) \\
\text { Electrolyte }(\mathrm{mm}) \\
\mathrm{O} 2 \text { electrode }(\mathrm{mm}) \\
\mathrm{O} 2 \text { current collector / flow channel }(\mathrm{mm})\end{array}$ & $\begin{array}{l}80 \times 80 \times 1.019 \\
10 \times 80 \times 1.019 \\
80 \times 80 \times 0.025 \\
80 \times 80 \times 0.140 \\
80 \times 80 \times 0.025 \\
80 \times 80 \times 1.019\end{array}$ \\
\hline
\end{tabular}

Table 2. Base case description and variation of parameters.

Base Case
- Mass flow rate $\mathrm{H} 2$ side $=8.0 \mathrm{e}-6 \mathrm{~kg} / \mathrm{s}$
- Mass flow rate $\mathrm{O} 2$ side $=4.0 \mathrm{e}-6 \mathrm{~kg} / \mathrm{s}$
- Mass fractions $\mathrm{H} 2$ side $: \mathrm{H} 2 \mathrm{O}=0.493902, \mathrm{H} 2=0.006098, \mathrm{~N} 2=0.50$
- Inlet temperature $\mathrm{H} 2$ and $\mathrm{O} 2 \mathrm{side}=1073 \mathrm{~K}$
Case 1: change only mass flow rate on $\mathrm{H} 2$ side to $15.0 \mathrm{e}-6 \mathrm{~kg} / \mathrm{s}$
Case 2: change only ref current exchange density on $\mathrm{H} 2 \mathrm{side}$ to $4000 \mathrm{~A} / \mathrm{m}^{2}$
Case 3: change only ref current exchange density on $\mathrm{O} 2$ side to $4000 \mathrm{~A} / \mathrm{m}^{2}$
Case 4: change only electrolyte specific resistivity to $0.1 \Omega-\mathrm{m}$
Case 5: change only cont resist electrodes and current collectors to $1.0 \mathrm{e}-4 \Omega-\mathrm{m}^{2}$
Case 6: change all parameters from cases $1-5$
Case 7. change $\gamma$ on concentration in activation overpotential from 0.5 to 1.0
Case 8. change $\gamma$ on concentration in activation overpotential from 0.5 to 0.1

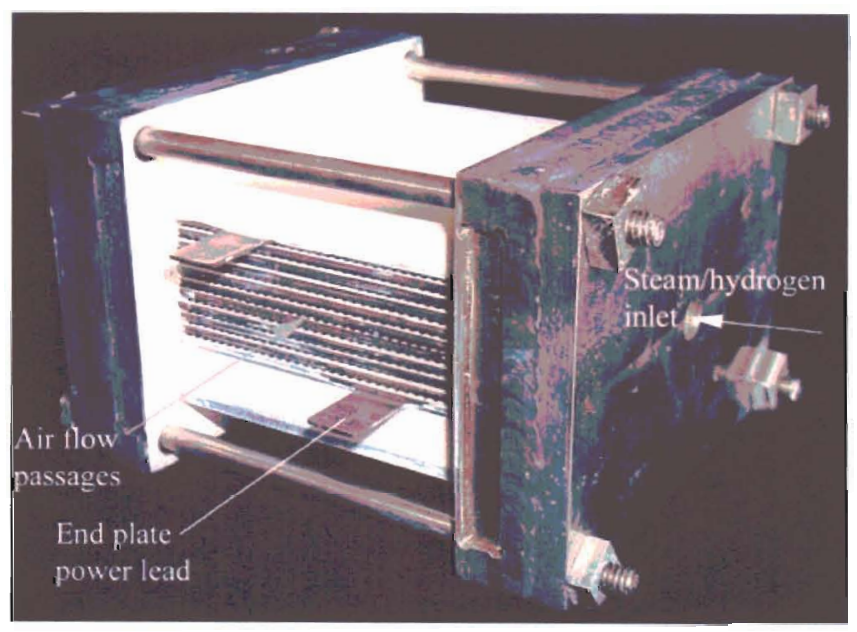

Figure 1. Detail of SOEC stack. 


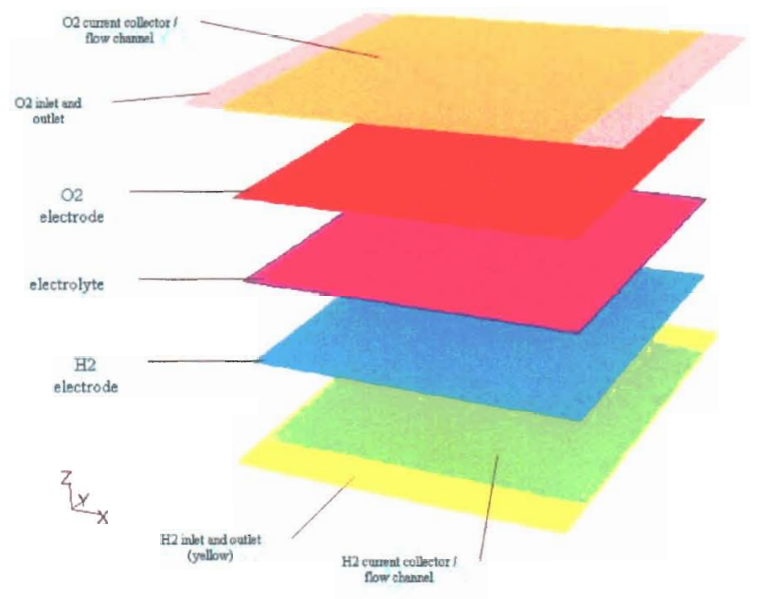

Figure 2. FLUENT single cell SOEC model.

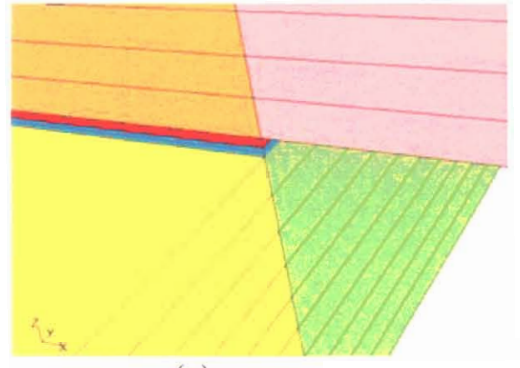

(a)

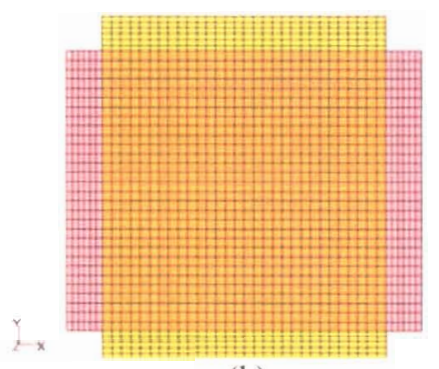

(b)

Figure 3. Details of 3D numerical mesh; (a) close-up of corner showing vertical element stacking, (b) top view showing grid.
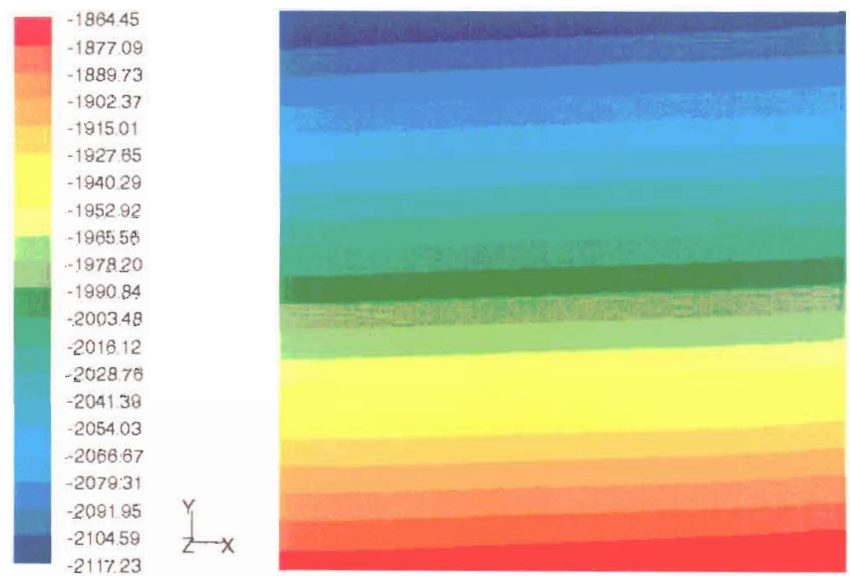

Figure 4. Contours of current density $\left(\mathrm{A} / \mathrm{m}^{2}\right)$ at $1.287 \mathrm{~V}$. 


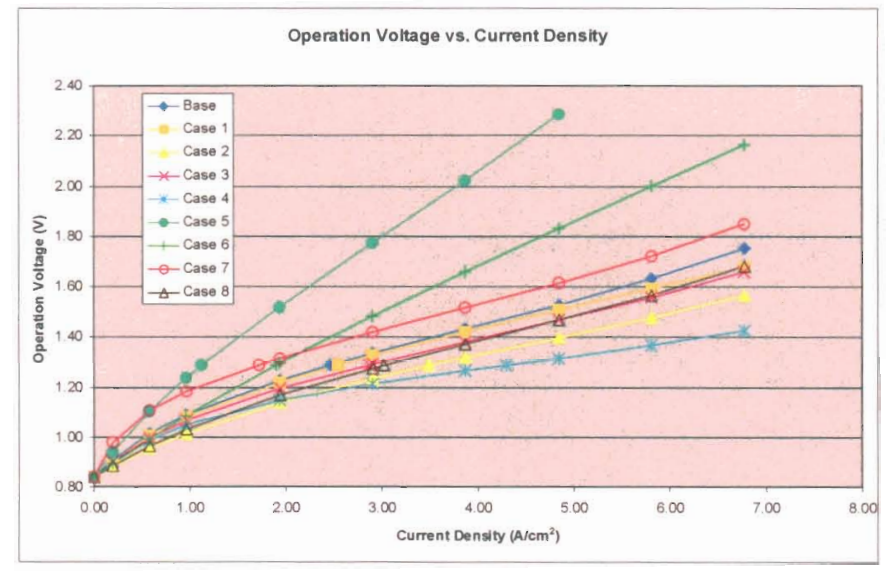

Figure 5. Operation voltage versus current density for various cases.

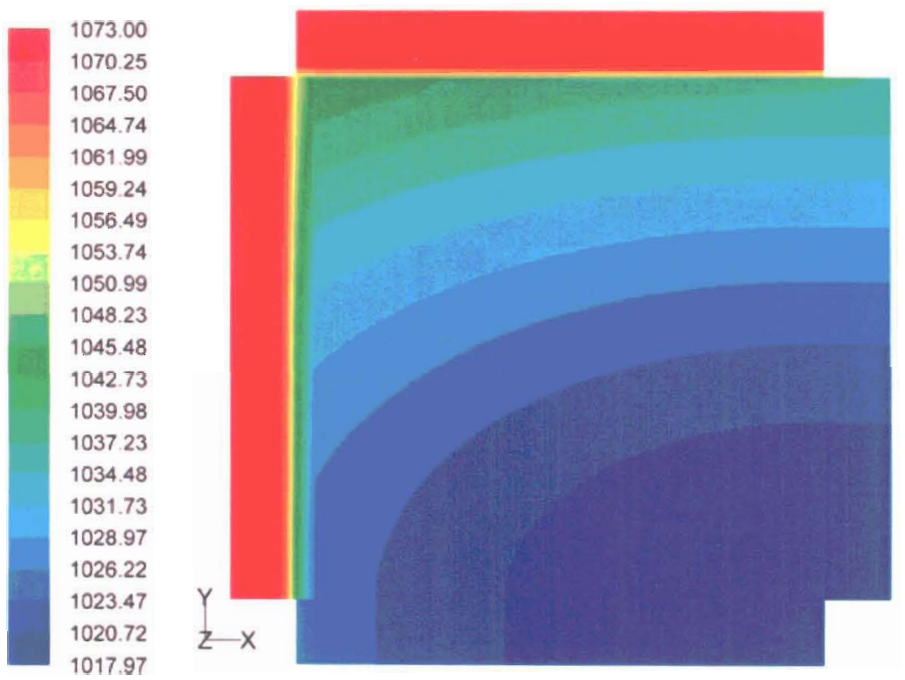

Figure 6. Temperature contours at $1.087 \mathrm{~V}$.

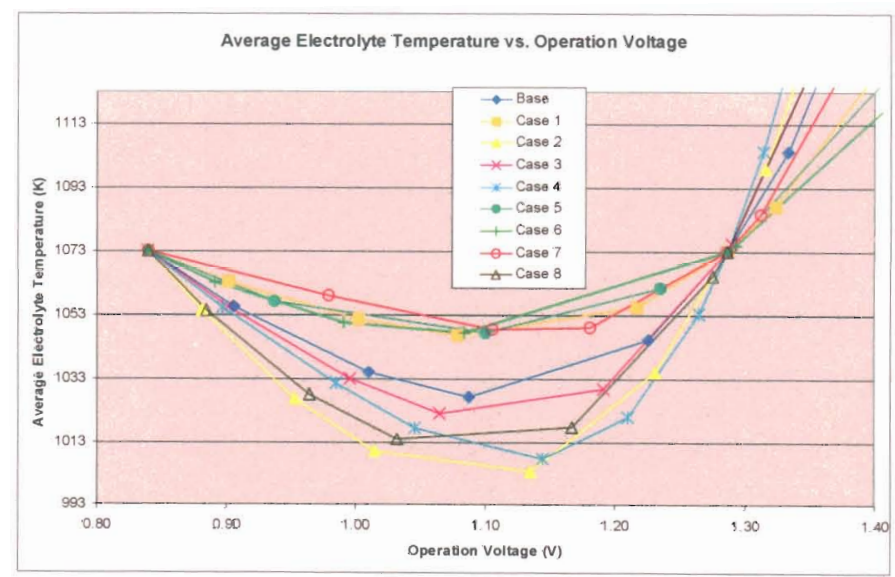

Figure 7. Mean electrolyte temperature versus operating voltage for various cases. 


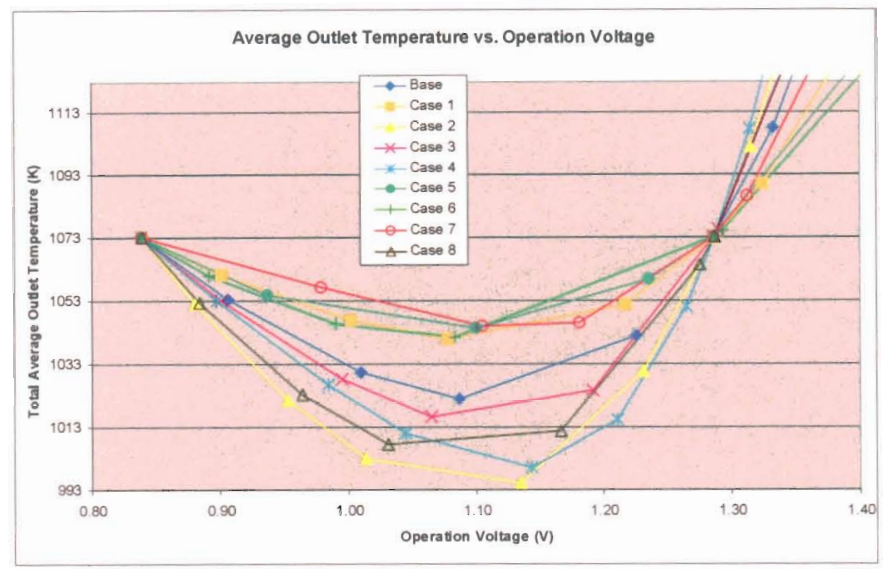

Figure 8. Average outlet gas temperature versus operating voltage for various cases.

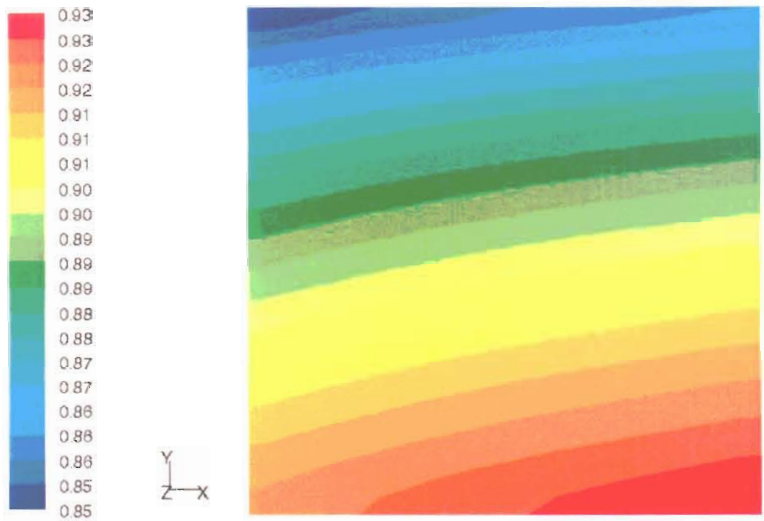

Figure 9. Contours of Nernst voltage at operating voltage of $1.287 \mathrm{~V}$.

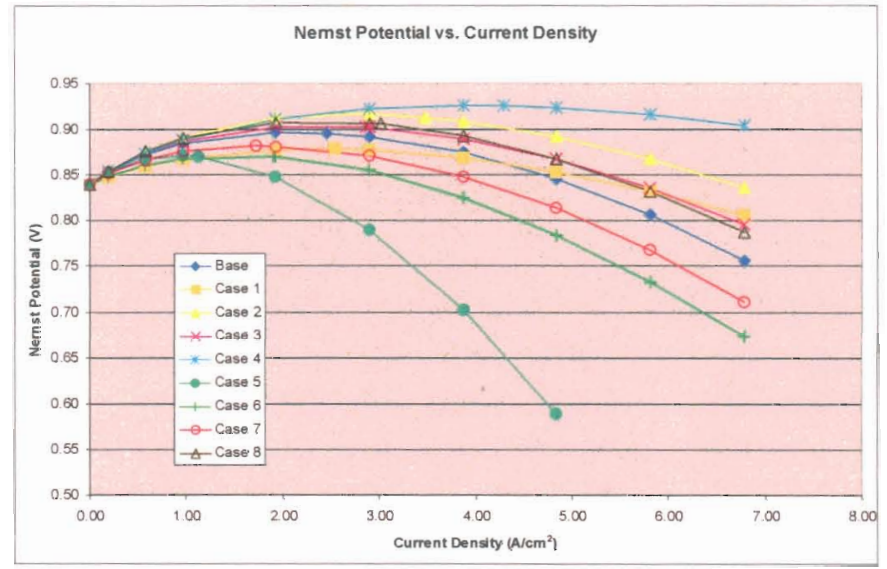

Figure 10. Average Nernst voltage versus current density for various cases. 


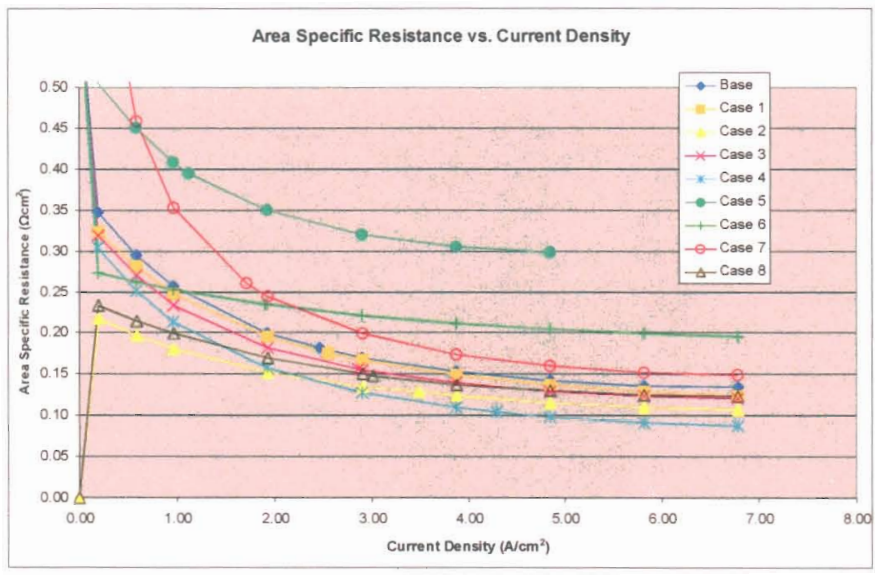

Figure 11. Per-cell area-specific resistance versus current density for various cases.
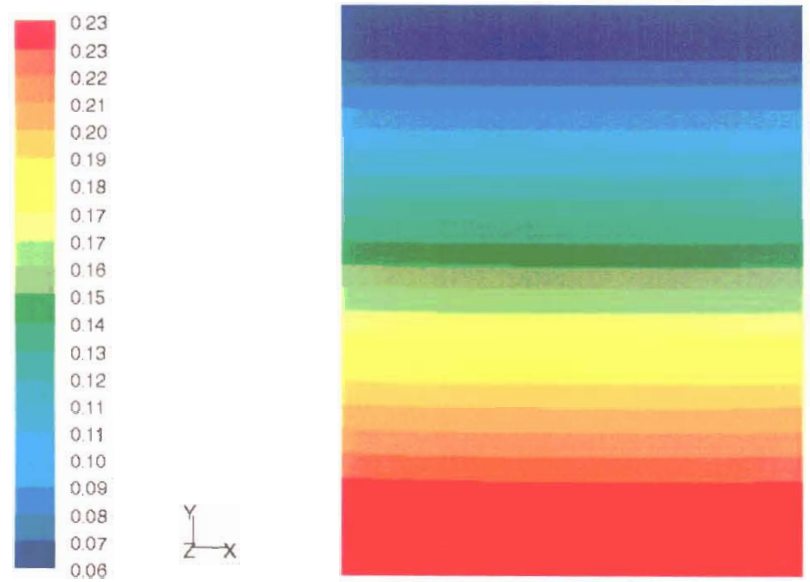

Figure 12. Contours of $\mathrm{H} 2$ mole fraction at operating voltage of $1.287 \mathrm{~V}$.
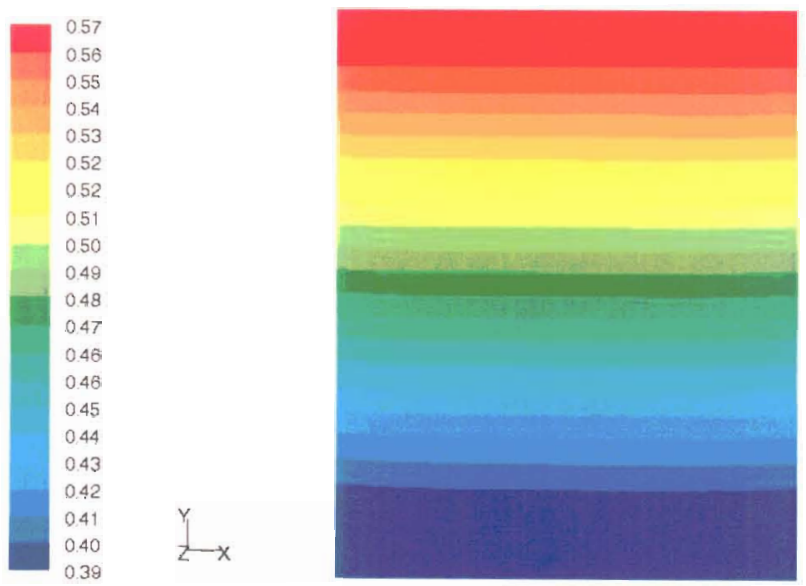

Figure 13. Contours of $\mathrm{H} 2 \mathrm{O}$ mole fraction at operating voltage of $1.287 \mathrm{~V}$. 


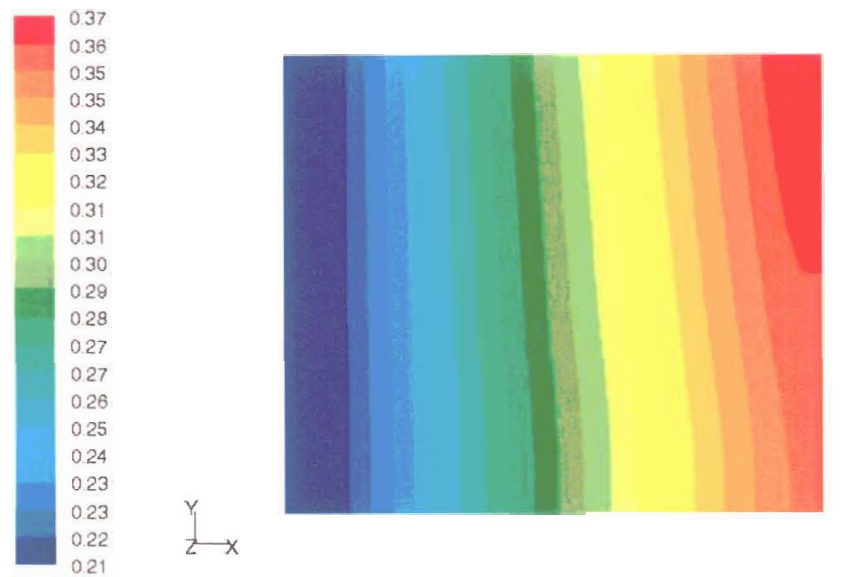

Figure 14. Contours of $\mathrm{O} 2$ mole fraction at operating voltage of $1.287 \mathrm{~V}$.

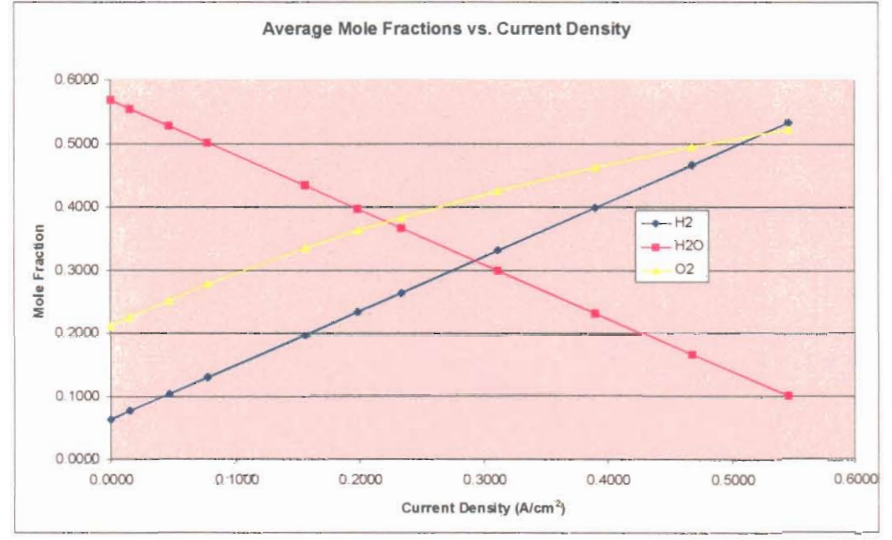

Figure 15. Outlet mole fraction versus current density for base case.

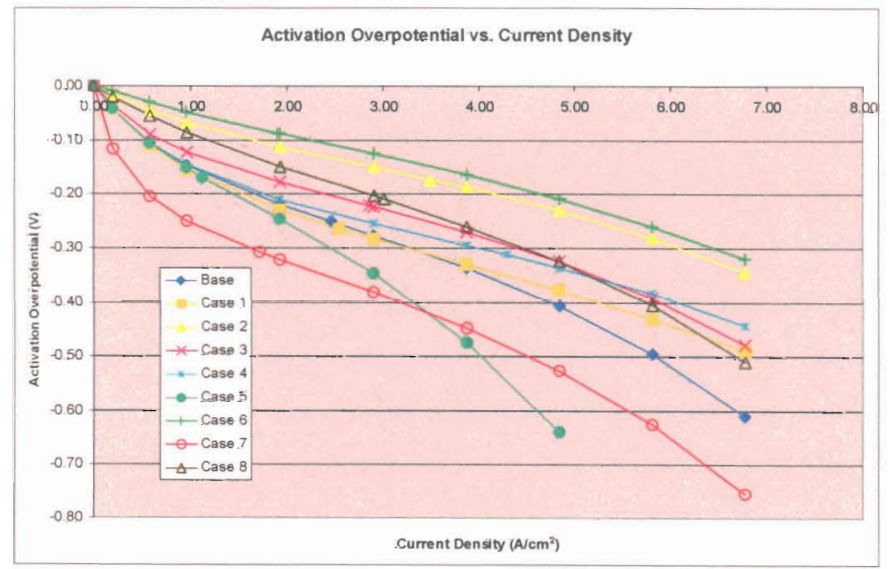

Figure 16. Total activation overpotential (V) for various cases. 